\title{
Enrichment and characterization of an anammox bacterium from a rotating biological contactor treating ammonium-rich leachate
}

Received: 21 August 2000 / Revised: 12 December 2000 / Accepted: 10 January 2001 / Published online: 22 February 2001

(C) Springer-Verlag 2001

\begin{abstract}
Anaerobic ammonium oxidation with nitrite to $\mathrm{N}_{2}$ (anammox) is a recently discovered microbial reaction with interesting potential for nitrogen removal from wastewater. We enriched an anammox culture from a rotating disk contactor (near Kölliken, Switzerland) that was used to treat ammonium-rich leachate with low organic carbon content. This enrichment led to a relative population size of $88 \%$ anammox bacteria. The microorganism carrying out the anammox reaction was identified by analysis of the 16S rDNA sequence and by fluorescence in situ hybridization (FISH) with 16S-rRNA-targeting probes. The percentage sequence identity between the $16 \mathrm{~S}$ rDNA sequences of the Kölliken anammox organism and the archetype anammox strain Candidatus Brocadia anammoxidans was $90.9 \%$, but between 98.5 and $98.9 \%$ with Candidatus Kuenenia stuttgartiensis, an organism identified in biofilms by molecular methods. The Kölliken culture catalyzed the anaerobic oxidation of ammonium with nitrite in a manner seemingly identical to that of Candidatus $B$. anammoxidans, but exhibited higher tolerance to phosphate (up to $20 \mathrm{mM}$ ) and to nitrite (up to $13 \mathrm{mM}$ ) and was active at lower cell densities. Anammox activity was observed only between $\mathrm{pH} 6.5$ and 9 , with an optimum at $\mathrm{pH} 8$ and a temperature optimum at $37^{\circ} \mathrm{C}$. Hydroxylamine and hydrazine, which are intermediates of
\end{abstract}

K. Egli · U. Fanger · P. J. J. Alvarez $\cdot$ H. Siegrist

J. van der Meer $(\bowtie)$. A. J. B. Zehnder

Eidgenössische Anstalt für Wasserversorgung,

Abwasserreinigung und Gewässerschutz (EAWAG),

Überlandstrasse 133, Postfach 611, 8600 Dübendorf, Switzerland

e-mail: vdmeer@eawag.ch,

Tel.: +41-1-8235438, Fax: +41-1-8235547

Present address:

U. Fanger

Andermatt Biocontrol AG,

Unterdorf, 6146 Grossdietwil, Switzerland

Present address:

P. J. J. Alvarez

Department of Civil and Environmental Engineering,

University of Iowa, Iowa City, IA 52242-1527, USA the anammox reaction of Candidatus $B$. anammoxidans, were utilized by the Kölliken organisms, and approximately $15 \%$ of the nitrite utilized during autotrophic growth was converted to nitrate. Electron microscopy showed a protein-rich region in the center of the cells surrounded by a doughnut-shaped region containing ribosomes and DNA. This doughnut-shape region was observed with FISH as having a higher fluorescence intensity. Similar to Candidatus B. anammoxidans, the Kölliken anammox organism typically formed homogenous clusters containing up to several hundred cells within an extracellular matrix.

Keywords Anaerobic ammonium oxidation - Anammox . Identification · Planctomycete · Fluorescence in situ hybridization · Electron microscopy $\cdot$ Physiology · Wastewater $\cdot$ Intermediates

\section{Introduction}

Nitrogen removal is an important aspect of wastewater treatment often accomplished by microbial processes such as nitrification and denitrification. These reactions have been known for a long time (Winogradsky 1890; Kluyver and Donker 1926; Beijerinck and Minkman 1910) and have been successfully applied in most modern wastewater treatment plants. Recently, a new microbial process for nitrogen removal was observed in a fluidized bed-reactor in Delft (The Netherlands) (Mulder et al. 1995). The process, called anaerobic ammonium oxidation (anammox), involves oxidation of ammonium to $\mathrm{N}_{2}$ with nitrite as electron acceptor under strictly anoxic conditions (Van de Graaf et al. 1995, 1996; Strous et al. 1997). ${ }^{15} \mathrm{~N}$-studies have shown that one $\mathrm{N}$-atom of the produced $\mathrm{N}_{2}$ originates from nitrite, whereas the other originates from ammonium. Hydroxylamine $\left(\mathrm{NH}_{2} \mathrm{OH}\right)$ and hydrazine $\left(\mathrm{N}_{2} \mathrm{H}_{4}\right)$ were identified as intermediates of the anammox process (Van de Graaf 1997).

$\mathrm{NH}_{4}{ }^{+}+\mathrm{NO}_{2}{ }^{-} \rightarrow \mathrm{N}_{2}+2 \mathrm{H}_{2} \mathrm{O}$ 
The existence of bacteria capable of catalyzing the anammox reaction (Eq. 1) had already been predicted in 1977 by Broda (1977) based on thermodynamic calculations. Further studies have shown that the anammox process is carried out by an autotrophic bacterium (Van de Graaf et al. 1996), which has recently been shown to belong to the order Planctomycetales and has been named Candidatus Brocadia anammoxidans (Strous et al. 1999a). This organism was also postulated to couple the oxidation of nitrite to nitrate for generating reducing equivalents for $\mathrm{CO}_{2}$ fixation (Van de Graaf et al. 1997). Candidatus B. anammoxidans grows slowly and has been reported to have a doubling time of 11 days at $\mathrm{pH} 8$ and $40^{\circ} \mathrm{C}$ (Jetten et al. 1999).

The advantages of the anammox process over the traditional combination of nitrification and denitrification for wastewater treatment are lower oxygen demand, which is needed by nitrifiers for partial oxidation of ammonium to nitrite, and no requirement for external carbon sources because the process is autotrophic. However, process startup could be hindered by the relatively low growth rate of anammox bacteria. Implementing the anammox process as a manageable wastewater treatment technology will also require a better understanding of the range of permissible nitrite, ammonium, and organic carbon loads, and oxygen and $\mathrm{pH}$ regimes.

The basic physiological aspects of the anammox process have been studied in depth mostly by a single research group in Delft (Jetten et al. 1999). However, anammox activity has been suspected for other wastewater treatment plants with uncharacterized high ammonium losses (Helmer and Kunst 1998; Siegrist et al. 1998; Schmid et al. 2000). To understand the anammox process and its importance in natural or engineered systems, it is desirable to identify other anammox bacteria besides the archetype strain Candidatus B. anammoxidans. Unfortunately, anammox organisms have been extremely difficult to cultivate in pure culture. Even Candidatus B. anammoxidans has only been purified to apparent homogeneity by Percoll density centrifugation (Strous et al. 1999a). Here, we describe the enrichment of anammox activity from biofilm material from a rotating biological contactor (RBC). Emphasis was placed on characterizing the anammox organism in this enrichment and on comparing its physiological characteristics to those of Candidatus $B$. anammoxidans.

\section{Material and methods}

\section{Biomass and mineral medium}

The culture was enriched from biofilm material from a nitrifying RBC in Kölliken near Aarau, Switzerland. This reactor exhibited $40-70 \%$ removal of nitrate at very low organic carbon concentrations (Siegrist et al. 1998). Anammox bacteria were enriched in 2.25-1 Schott flasks containing approximately 21 mineral medium with ammonium as electron donor, nitrite as electron acceptor and bicarbonate as carbon source. The bottles were closed with gastight butyl septa and incubated in an anaerobic chamber filled with nitrogen gas and traces of $\mathrm{H}_{2}$. The initial $\mathrm{pH}$ was 7 and was adjusted regularly with $\mathrm{HCl}$.
The medium contained initially in demineralized water: $3 \mathrm{mM}$ $\left(\mathrm{NH}_{4}\right)_{2} \mathrm{SO}_{4}, 6 \mathrm{mM} \mathrm{NaNO}, 25 \mathrm{mM} \mathrm{KHCO} 3,1 \mathrm{mM} \mathrm{K} \mathrm{HPO}_{4}, 0.5 \mathrm{mM}$ $\mathrm{CaCl}_{2}, 0.5 \mathrm{mM} \mathrm{MgCl}, 2 \mathrm{ml}$ of trace element solution 1 and $1 \mathrm{ml}$ trace element solution 2 per liter. Trace element solution 1 contained (per liter demineralized water) $10 \mathrm{~g} \mathrm{Na} 2$ EDTA $2 \mathrm{H}_{2} \mathrm{O}$ and $5 \mathrm{~g} \mathrm{FeSO}_{4}$. Trace element solution 2 contained (per liter demineralized water) $15 \mathrm{~g} \mathrm{Na}_{2}$ EDTA $2 \mathrm{H}_{2} \mathrm{O}, 0.43 \mathrm{~g} \mathrm{ZnSO} \cdot 7 \mathrm{H}_{2} \mathrm{O}, 0.24 \mathrm{~g}$ $\mathrm{CoCl}_{2} \cdot 6 \mathrm{H}_{2} \mathrm{O}, 0.99 \mathrm{~g} \mathrm{MnCl}_{2} \cdot 4 \mathrm{H}_{2} \mathrm{O}, 0.25 \mathrm{~g} \mathrm{CuSO}_{4} \cdot 5 \mathrm{H}_{2} \mathrm{O}, 0.22 \mathrm{~g}$ $\mathrm{NaMoO}_{4} \cdot 2 \mathrm{H}_{2} \mathrm{O}, 0.19 \mathrm{~g} \mathrm{NiCl}_{2} \cdot 6 \mathrm{H}_{2} \mathrm{O}, 0.08 \mathrm{~g} \mathrm{Na}_{2} \mathrm{SeO}_{3}, 0.014 \mathrm{~g}$ $\mathrm{H}_{3} \mathrm{BO}_{4}$.

\section{Physiological experiments}

All experiments were performed in 60-ml serum bottles filled with $43 \mathrm{ml}$ medium and inoculated with $2 \mathrm{ml}$ of an anammox bacteria suspension from the enrichment culture. The bottles contained a 15-ml headspace and were closed with butyl rubber stoppers (Maagtechnic, Dübendorf, Switzerland) and aluminum crimp seals. After inoculating the anammox culture and before starting incubations, the headspace was exchanged by applying several cycles of vacuum and overpressure (1.5 bar) or by flushing with a gas mixture containing $20 \%$ (mol\% or mol-ppm) $\mathrm{CO}_{2}(99.998 \%$ purity) and $80 \% \mathrm{He}(99.9990 \%)$. The initial gas pressure of the headspace was 1.5 bar. All experiments were performed in triplicate at $37^{\circ} \mathrm{C}$ and $\mathrm{pH} 7$, unless stated otherwise. To study the effect of $\mathrm{pH}$, a $20 \mathrm{mM}$ phosphate buffer was used for experiments between $\mathrm{pH}$ 6 and 8 , and a $50 \mathrm{mM}$ Tris/HCl-buffer was used for the range between $\mathrm{pH} 8$ and 9. The initial $\mathrm{pH}$ of the medium was adjusted by mixing different amounts of $\mathrm{KH}_{2} \mathrm{PO}_{4}$ and $\mathrm{K}_{2} \mathrm{HPO}_{4}$ and remained constant during the experiment. In the $\mathrm{pH}$ experiments, the headspace was flushed only with $\mathrm{He}(99.996 \%)$, and only $1 \mathrm{mM}$ instead of $25 \mathrm{mM} \mathrm{KHCO}$ was added. In control experiments without ammonium or nitrite, $\left(\mathrm{NH}_{4}\right)_{2} \mathrm{SO}_{4}$ or $\mathrm{NaNO}_{2}$ were replaced with $2 \mathrm{mM}$ $\mathrm{Na}_{2} \mathrm{SO}_{4}$. In experiments testing oxygen sensitivity, initial oxygen concentrations were set at $0.25,0.5,1$ and $18 \%$. Different amounts of oxygen gas were added to reach the different concentrations. The bottles containing $18 \% \mathrm{O}_{2}$ were flushed after $64 \mathrm{~h}$ with aligal62 $\left[=20 \% \mathrm{CO}_{2}(99.5 \%)\right.$ and $80 \%$ Ar (99.996\%)]. All gases were purchased from Carbagas (Rümlang, Switzerland).

\section{Nucleic acid extraction}

Genomic nucleic acids were isolated from a $15-\mathrm{ml}$ sample from the enrichment culture after four rounds of subculturing. The cells were pelleted and resuspended in a screw-capped vial in $1 \mathrm{ml}$ of homogenization buffer $(200 \mathrm{mM}$ Tris- $\mathrm{HCl} \mathrm{pH} 8.5,1.5 \%$ SDS, $10 \mathrm{mM}$ EDTA, $1 \%$ sodium desoxycholate, $1 \%$ nonidet-P40, $5 \mathrm{mM}$ urea and $10 \mathrm{mM}$ dithiothreitol). Glass beads $(0.5 \mathrm{~g}, 0.1 \mathrm{~mm}$ in diameter) were added and the mixture was shaken twice for $1 \mathrm{~min}$ at 4,000 rpm in a Braun Cell Homogenizer (Inotech, Dottikon, Switzerland) with a 1-min interval on ice. The glass beads were allowed to settle without centrifugation, and the supernatant was transferred to a fresh Eppendorf tube. This sample was mixed 1:1 with acidic phenol (pH 5.3) and incubated in a water bath at $65^{\circ} \mathrm{C}$ for $5 \mathrm{~min}$ (Aiba et al. 1981). After vortexing and centrifugation for $5 \mathrm{~min}$ at $15,000 \times g$ and $4{ }^{\circ} \mathrm{C}$, the water phase was transferred to a new Eppendorf tube and mixed 1:1 (v/v) with Tris-HCl-buffered phenol ( $\mathrm{pH} 8.0)$. After vortexing, chloroform/isoamylalcohol (24:1 $\mathrm{v} / \mathrm{v}$ ) was added, vortexed and centrifuged for $5 \mathrm{~min}$ as before. The water phase was again recovered and extracted with $1 \mathrm{ml}$ of chloroform/ isoamylalcohol as before. The supernatant was transferred into a new Eppendorf tube, and DNA and RNA were pelleted with 0.7 volumes isopropanol and 0.1 volumes 3 -M sodium acetate (pH 5.2) for $1 \mathrm{~h}$ at $-80^{\circ} \mathrm{C}$. The tube was subsequently centrifuged for $15 \mathrm{~min}$ at $15,000 \times \mathrm{g}$ to recover nucleic acids. The pelleted nucleic acids were washed with a solution of $70 \%(\mathrm{vol} / \mathrm{vol})$ ethanol and $30 \%$ of a solution of $10 \mathrm{mM}$ Tris- $\mathrm{HCl}$ and $1 \mathrm{mM}$ EDTA ( $\mathrm{pH}$ 8.0) dissolved in RNase-free water. 


\section{Amplification of 16S rDNA}

16S rDNA fragments from isolated total DNA of the enrichment culture were amplified with Taq DNA polymerase (GIBCO BRL, Life Technologies, Gaithersburg, Md.). The following eubacterial primers were used: $16 \mathrm{~S} 6 \mathrm{~F}\left(5^{\prime}\right.$-ggagagttagatcttggctcag-3') and $16 \mathrm{~S}$ 1510R (5'-gtgctgcagggttaccttgttacgact- $\left.3^{\prime}\right)$. As anammox-specific primers we used Pla46rc (5'-ggattaggcatgcaagtc-3') and Amx820 $\left(5^{\prime}\right.$-aaaaccctctacttagtgccc- $\left.3^{\prime}\right)$. Dimethylsulfoxide was added at $5 \%$. Conditions for PCR were as suggested by the supplier, but with a cycling regime of: $4 \mathrm{~min}$ at $95^{\circ} \mathrm{C}$, then 35 cycles each of $45 \mathrm{~s}$ at $95^{\circ} \mathrm{C}, 45 \mathrm{~s}$ at $56^{\circ} \mathrm{C}$, and $1 \mathrm{~min}$ at $70^{\circ} \mathrm{C}$. Final extension was carried out for $3 \mathrm{~min}$ at $72^{\circ} \mathrm{C}$. The $16 \mathrm{~S}$ rDNA PCR products were cloned in Escherichia coli DH5 $\alpha$ in vector pGEM-T-easy (Promega, Wallisellen, Switzerland) by established procedures (Sambrook et al. 1989). Plasmid DNAs for sequencing were isolated by boiling preparation (Sambrook et al. 1989). Plasmid inserts were sequenced on both strands by using a Thermosequenase Kit (Amersham, Little Chalfont, UK) with IRD-800 and IRD-700 labeled primers (MWG Biotech, Ebersberg, Germany). Universal vector-located primer sequences were used and, in addition, two primers which targeted a conserved region around position 785 of the cloned 16S rDNA fragment: EUB785R (5'-ggattagatacctggtag- $\left.3^{\prime}\right)$ and EUB785F ( $5^{\prime}$-ctaccagggtatctaatc- $\left.3^{\prime}\right)$. Sequence transcripts were separated and analyzed on a LiCOR 4200L IR ${ }^{2}$ automated DNA sequencer (LiCOR, Lincoln, Neb.). The nucleotide sequence of the 16S rRNA gene of the Kölliken anammox organism was deposited in the GenBank database under accession no. AJ250882. Sequence comparisons were calculated by direct FastA alignments (Pearson and Lipman 1988).

\section{Analytical measurements}

Concentrations of $\mathrm{O}_{2}$ and $\mathrm{N}_{2}$ were measured with a gas chromatograph (GC) (type GC-8A; Shimadzu, Tokyo, Japan). A gas volume of $1 \mathrm{ml}$ (at the pressure existing in the sample flask) was injected with a gas-tight syringe (GC syringe series A2; Supelco, Switzerland). The carrier gas was helium (99.999\%). The GC was equipped with a thermal conductivity detector and two parallel packed columns. One column was packed with molecular sieve 5A 80/100 (Brechbühler, Schlieren, Switzerland), the other with Porapack Q 80/100 (Brechbühler).

The concentration of nitrate was quantified by ion-exchange chromatography using a DX500-apparatus with IONPAC-ATC1 (anion trap column), IONPAC-AG11 guard column, an analytical IONPAC-AS11-4-mm column, ASRSII-4-mm suppressor, and CD20 conductivity detector (Dionex, Olten, Switzerland).

The concentration of $\mathrm{NO}_{2}^{-}$was determined either with ion chromatography as described above or colorimetrically. For the colorimetric quantification, cells were removed from the sample by centrifugation. Fifty $\mu \mathrm{l}$ of the sample was mixed with $950 \mu \mathrm{l}$ of the reagent, which contained $1 \%$ sulfanilic acid, $0.05 \% N$-(1-naphthyl)-ethylene diammoniumdichloride (Riedel-deHaën, purchased from Fluka, Switzerland) and $1 \mathrm{M}$ of $\mathrm{H}_{3} \mathrm{PO}_{4}$. After $5 \mathrm{~min}$ of incu- bation at room temperature, the color development was complete and the absorbance at $540 \mathrm{~nm}$ was determined.

Ammonium was analyzed spectrophotometrically as described elsewhere (Scheiner 1976). Phenol reagent $(0.4 \mathrm{ml})$ and hypochlorite reagent $(0.6 \mathrm{ml})$ were added to a $1 \mathrm{ml}$ sample, followed by incubation at room temperature in the dark for at least $2 \mathrm{~h}$. The absorbance was measured at $635 \mathrm{~nm}$.

The concentration of hydroxylamine $\left(\mathrm{NH}_{2} \mathrm{OH}\right)$ was determined according to the method of Frear and Burrel (1955). The following reagents were used: $1 \mathrm{~g}$ 8-quinolinol dissolved in $100 \mathrm{ml}$ absolute ethanol, $1 \mathrm{M}$ sodium carbonate, $12 \%(\mathrm{w} / \mathrm{v})$ trichloroacetic acid and $0.05 \mathrm{M}$ sodium phosphate buffer $\mathrm{pH}$ 6.8. Sodium phosphate-buffer $\mathrm{pH} 6.8(0.3 \mathrm{ml})$ and trichloroacetic acid solution $(60 \mu \mathrm{l})$ were added to the sample $(50 \mu \mathrm{l})$, which was followed by the addition of 8 -quinolinol solution $(0.3 \mathrm{ml})$. The solution was mixed, and the tube was closed and placed in a boiling water bath for $1 \mathrm{~min}$. After cooling for $15 \mathrm{~min}$ at room temperature, the absorbance was measured at $705 \mathrm{~nm}$.

The concentration of hydrazine $\left(\mathrm{N}_{2} \mathrm{H}_{4}\right)$ was measured according to Watt (1952). A 50- $\mu 1$ sample was incubated for $10 \mathrm{~min}$ at room temperature with $0.95 \mathrm{ml}$ of a reagent containing $0.4 \mathrm{~g} p$-dimethylaminobenzaldehyde, $20 \mathrm{ml}$ ethanol and $2 \mathrm{ml}$ of $37 \% \mathrm{HCl}$. The absorbance was measured at $458 \mathrm{~nm}$. The absorbance increased linearly with hydrazine up to concentrations of $0.4 \mathrm{mM}$.

All spectrophotometric measurements were performed with a Uvikon 860 spectrophotometer (Kontron, Switzerland).

\section{In situ hybridization}

Cells were recovered by centrifugation and resuspended in phosphate-buffered saline (PBS), $\mathrm{pH} 7.4$, consisting of $8 \mathrm{~g} \mathrm{NaCl}, 0.2 \mathrm{~g}$ $\mathrm{KCl}, 1.44 \mathrm{~g} \mathrm{Na}_{2} \mathrm{HPO}_{4}$ and $0.24 \mathrm{~g} \mathrm{KH}_{2} \mathrm{PO}_{4}$ per liter distilled water. The samples were fixed by adding three volumes of $4 \%$ paraformaldehyde (in PBS), mixing and incubating for $3 \mathrm{~h}$ on ice. Afterwards, the cells were washed twice with PBS. The fixed cells were suspended in a solution of 50\% PBS and 50\% ethanol, and the mixture was stored at $-20^{\circ} \mathrm{C}$. Glass slides (Huber and $\mathrm{Co}$. Reinach, Switzerland) were coated with gelatin (Amann et al. 1990). Between 2 and $10 \mu \mathrm{l}$ of a fixed sample was applied on a well of the coated slide, dried for $3 \mathrm{~h}$ at $45^{\circ} \mathrm{C}$ and sequentially dehydrated in solutions of $50 \%, 80 \%$ and $100 \%$ ethanol (vol $/ \mathrm{vol}$ ) in PBS for $3 \mathrm{~min}$ each. To start hybridization, $9 \mu \mathrm{l}$ of hybridization buffer (containing the appropriate $\mathrm{NaCl}$ and formamide concentration for the used probe, Table 1) and $1 \mu \mathrm{l}$ of a fluorescently labeled probe (at a concentration of $50 \mathrm{ng} / \mu \mathrm{l}$ ) were added to a well. The hybridization was conducted for $90 \mathrm{~min}$ at $45^{\circ} \mathrm{C}$ in a humidified chamber.

Following hybridization, a stringent washing step was performed for $15 \mathrm{~min}$ at $48^{\circ} \mathrm{C}$ in a buffer with the appropriate $\mathrm{NaCl}$ concentration (Table 1), $20 \mathrm{mM}$ Tris- $\mathrm{HCl}, \mathrm{pH}$ 7, 5 mM EDTA and $0.01 \%$ SDS. The samples were counterstained with DAPI (4,6-diamidino-2-phenylindole) at a final concentration of $10 \mathrm{mg} / \mathrm{l}$ for $5 \mathrm{~min}$ at room temperature and mounted in Citifluor (Citifluor, London, UK).
Table 1 Probes used for fluorescence in situ hybridization

\begin{tabular}{lllll}
\hline Probe & Sequence $\left(5^{\prime} \rightarrow 3^{\prime}\right)$ & $\begin{array}{l}\text { Formamide } \\
\text { concentration }\end{array}$ & $\begin{array}{l}\text { Wash buffer } \\
\text { NaCl }(\mathrm{mM})\end{array}$ & Reference \\
\hline EUB338 & getgectcccgtaggagt & $0 \%$ & 900 & Amann et al. (1990) \\
Alf1b & cgttcgytctgagccag & $20 \%$ & 225 & Manz et al. (1992) \\
Amx820 & aaaaccctctacttagtgccc & $25 \%$ & 159 & Strous (2000) \\
Amx1240 & tttagcatcctttgtaccaacc & $60 \%$ & 14 & Strous (2000) \\
Bet42a & gecttccacttcgttt & $35 \%$ & 80 & Manz et al. (1992) \\
Kst1273 & tcggctttataggtttcgca & $25 \%$ & 159 & Schmid et al. (2000) \\
NIT3 & cctgtgctccatgctccg & $35 \%$ & 80 & Wagner et al. (1996) \\
Ntspa662 & ggaattccgcgctcctct & $35 \%$ & 80 & Daims et al. (2000) \\
Pla46 & gacttgcatgcctaatcc & $30 \%$ & 112 & Neef et al. (1998) \\
\hline
\end{tabular}


All oligonucleotide probes were obtained from Microsynth (Balgach, Switzerland). Microscopy was performed on an Olympus BX50 microscope, equipped with filters HQ-CY3, HQ-FITC and HQ-DAPI (all from AF Analysentechnik). Digital images were taken with a CCD camera (type Sensys, Photometrics, Tuscon, Ariz., USA) and acquired in the program METAVIEW (Visitron, Puchheim, Germany). The relative population size of the anammox bacteria in the enrichment was determined by confocal laser scanning microscopy by M. Schmid at the Technical University of Munich on paraformaldehyde-fixed samples, stained with probe Amx820 and counterstained with SYBR Green I, according to Schmid et al. (2000).

Electron microscopy

Freeze-fraction and transmission electron microscopy were carried out by E. Wehrli from the Laboratory for Electron Microscopy I, the central electron microscopy facility of the Biology Department of the Swiss Federal Institute of Technology (ETH-Zürich). Samples were prepared as described elsewhere (Wehrli and Egli, 1988).

Protein measurements

Protein concentrations were measured using the Bio-Rad protein assay (Bio-Rad Laboratories, Munich, Germany). Cell suspensions $(2 \mathrm{ml})$ were pelleted, resuspended in the same amount of $0.1 \mathrm{M}$ $\mathrm{NaOH}$ and incubated for $1.5 \mathrm{~h}$ at $80^{\circ} \mathrm{C}$. An $0.8 \mathrm{ml}$-aliquot of this suspension was incubated with $0.2 \mathrm{ml}$ of Bio-Rad dye-reagent for $15 \mathrm{~min}$. The absorbance was measured at $595 \mathrm{~nm}$. A standard curve was prepared from known concentrations bovine serum albumin (Fraction V, Sigma).

\section{Results}

\section{Enrichment of anammox bacteria}

Anammox activity was previously observed in an RBC operated at the landfill site in Kölliken (near Aarau, Switzerland) (Koch et al. 2000). The RBC was used to treat ammonium-rich leachate with low organic carbon content. Cultures incubated under anoxic conditions with approximately $0.5 \mathrm{~g}$ of biofilm material scratched from the RBC in 11 of mineral medium immediately converted nitrite $(6 \mathrm{mM})$ and ammonium $(5.2 \mathrm{mM})$. After several additions of nitrite and ammonium to the same culture flask (in each case to a final concentration of 6 and $5.2 \mathrm{mM}$, respectively), stable production rates of dinitrogen and nitrate were obtained (data not shown) and the culture density increased slowly. The culture had a brownish-red color, probably due to a high cytochrome content (Jetten et al. 1999). After reaching an $\mathrm{OD}_{600 \mathrm{~nm}}$ of 0.08 , the enrichment culture was diluted tenfold and used to inoculate a new flask. This dilution and enrichment procedure was repeated three more times within 6 months and led to an increase of the relative population size of anammox bacteria in the culture.

The enrichment culture was subsequently analyzed for the presence of anammox bacteria by cloning amplifiable 16S rDNA fragments, and by fluorescence in situ hybridization (FISH). Total DNA was isolated from the enrichment culture and 16S rDNA fragments were amplified by
PCR using conserved eubacterial primers for almost the entire 16S rDNA length or using the primers Pla46rc and Amx820 (Table 1). The fragments were cloned, sequenced and compared to entries in the GenBank database. Among eleven plasmid inserts in the full-length $16 \mathrm{~S}$ rDNA library, six were identical and revealed $90.9 \%$ sequence identity to the $16 \mathrm{~S}$ rDNA sequence of Candidatus $B$. anammoxidans (Strous et al. 1999a, GenBank accession number AJ131819). On the basis of such a high percentage of sequence identity with the archetype anammox bacterium, we suspected this $16 \mathrm{~S}$ rDNA fragment to be representative of possible anammox bacteria in the Kölliken enrichment culture. Furthermore, the percentages of sequence identity of this 16S rDNA fragment of the Kölliken enrichment culture with 16S rDNA fragments derived from biofilm material of a trickling filter operating in Stuttgart were between $98.5 \%$ and $98.9 \%$ (from a 1407 nucleotide overlap), as determined by direct FastA alignments (GenBank accession numbers AF202655-AF202663, Schmid et al. 2000). The 16S rDNA fragments analyzed from the reactors in Stuttgart have been proposed to originate from anammox microorganisms that were classified as Candidatus Kuenenia stuttgartiensis (Schmid et al. 2000). Therefore, the organisms enriched from the biofilm material from Kölliken seem more similar to Candidatus $K$. stuttgartiensis and less similar to Candidatus $B$. anammoxidans. We verified whether the near-full length 16S rDNA sequence of the Kölliken enrichment was representative for anammox bacteria in the culture by reamplifying a specific part of the 16S rDNA using one primer targeting a region conserved for Planctomycetales (Pla46rc) and one for all known anammox bacteria (Amx820). Eleven cloned 16S rDNA fragments were sequenced, which were all identical to the previously determined, near-full length $16 \mathrm{~S}$ rDNA sequence.

Based on the cloned 16S rDNA sequence from Kölliken, we verified the presence of anammox bacteria in the enrichment culture by FISH. Two oligonucleotide probes (Amx820 and Amx1240), which previously were found to specifically detect Candidatus $B$. anammoxidans in Delft enrichments (Strous 2000), reacted positively with most organisms in our enrichment culture (Fig. 1). The probe Kst1275, which was developed for the anammox bacteria in Stuttgart (Schmid et al. 2000), reacted positively as well. Several other oligonucleotide probes specific for Candidatus B. anammoxidans (i.e., Amx156, Amx223 and Amx1154, Schmid et al. 2000) did not react with the Kölliken organism, and the target sequences for these probes were not conserved in the 16S rDNA sequence derived from the Kölliken organism (not shown).

Other general probes that reacted positively with most cells in the Kölliken biofilm enrichment were the ALF1b probe for $\alpha$-Proteobacteria, the EUB338 general eubacterial probe, and the Pla46 probe for the order Planctomycetales (Neef et al. 1998). Similar to Candidatus B. anammoxidans (Strous 2000), FISH-stained cells typically had an inner area with very low fluorescence intensity (Fig. 1). By counting FISH-stained cells with different specific probes, we estimated that the enrichment culture con- 


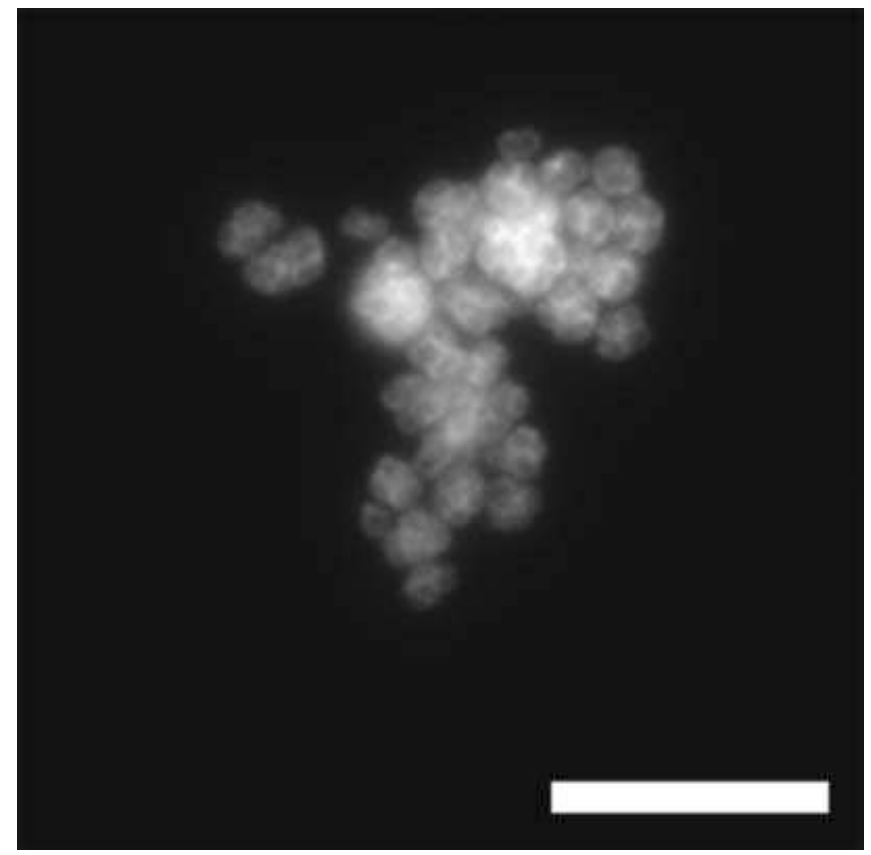

Fig. 1 Sample from the Kölliken anammox enrichment culture, stained with the probe Amx820. Note the optically lighter inside of the cells which results in their "doughnut" appearance. Bar $10 \mu \mathrm{m}$

tained approximately 90\% anammox organisms (of all DAPI-stained cells). Very precise determination, however, was difficult since the anammox organisms tended to form stable and relatively large clusters (Figs. 1 and 2). By using confocal laser scanning microscopy on FISHstained samples, a relative biovolume for the anammox population of $88 \% \pm 5 \%$ could be determined (M. Schmid, personal communication). Since the probes Amx820, Kst1275, Amx1240 and Pla46 all stained the majority of the cells in the enrichment culture, and since positively reacting cells were all of the same type, we concluded that the derived 16S rDNA sequence originated from the majority of cells in the enrichment. These cells most likely represent anammox bacteria; however, they differed from the Delft archetype strain B. anammoxidans. Furthermore, no positively stained cells were observed with the probes Bet42a (Manz et al. 1992) for the $\beta$-Proteobacteria, indicative of the genus Nitrosomonas, Ntspa662 for Nitrospira (Daims et al. 2000) and Nit3 (Wagner et al. 1996) for the genus Nitrobacter.

Thin sections of fixed enrichment samples were also analyzed by transmission and freeze-fraction electron microscopy (Fig. 2). Typically, clusters of different size were

Fig. 2A-D Electron micrographs of Kölliken anammox cells. Freeze-fractions show cells with a large extracellular polymer matrix $(E$, panel A) and the S-layer $(S)$ and the outer membrane $(O$, panel B). With transmission electron microscopy a protein-rich area $(P)$ within the cells (dark region, panel $\mathbf{C}$ ), the (now reduced) extracellular polymer layer $(E)$ and the membranes $(M)$ are to be seen, panel D) Small compact clusters of anammox cells. Bar $1 \mu \mathrm{m}$
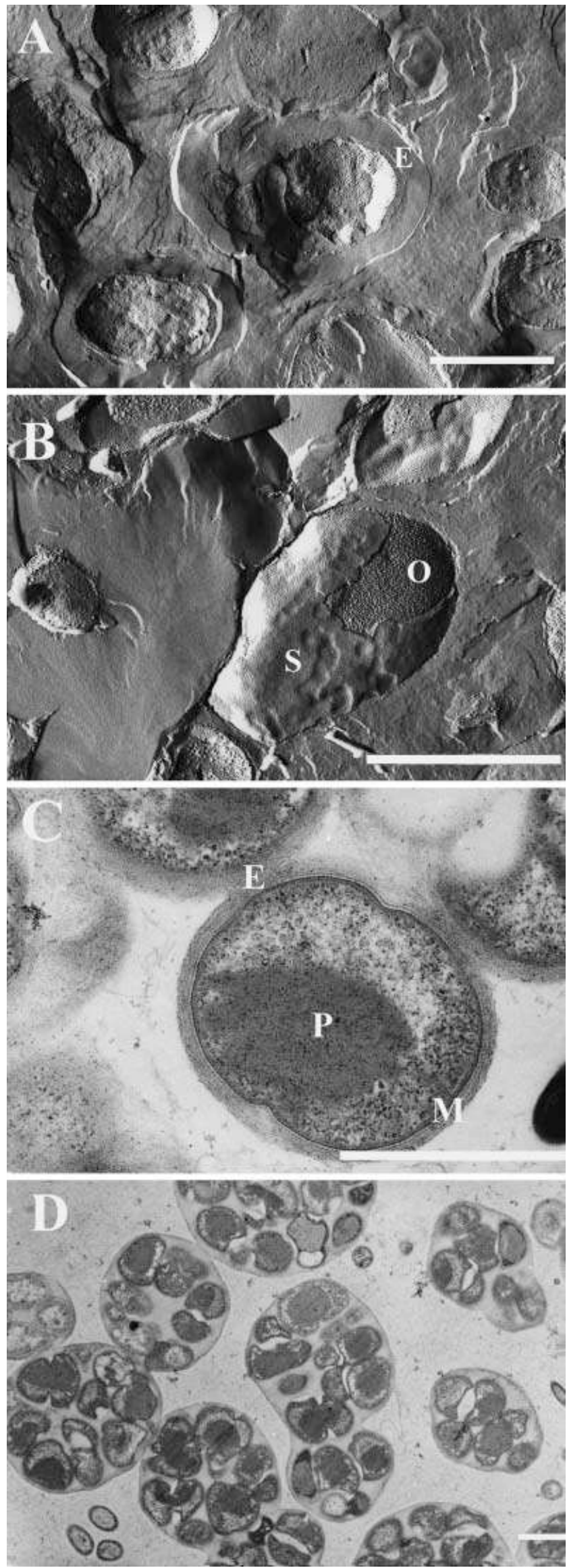


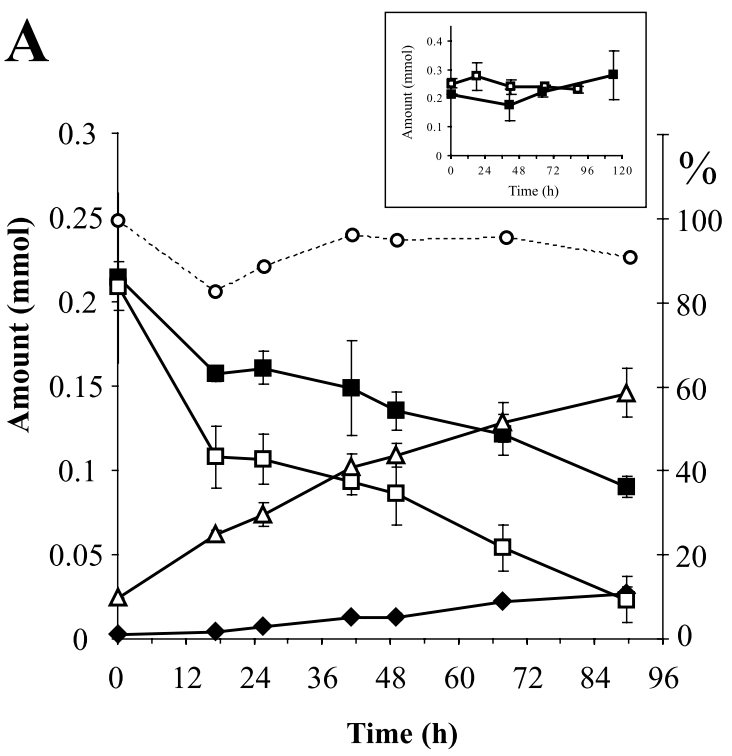

Fig. 3A, B Anammox activity of the enrichment culture at $\mathrm{pH} 7.5$ and $37^{\circ} \mathrm{C}$. A Disappearance of $\mathrm{NH}_{4}{ }^{+}$and $\mathrm{NO}_{2}{ }^{-}$and concomitant formation of $\mathrm{N}_{2}$ and $\mathrm{NO}_{3}{ }^{-}$. Note that the $y$-axis shows the total amount of $\mathrm{NH}_{4}{ }^{+}, \mathrm{NO}_{2}{ }^{-}, \mathrm{NO}_{3}{ }^{-}$and $\mathrm{N}_{2}$ in mmol per incubation flask (=45 ml liquid volume, $15 \mathrm{ml}$ headspace). Total mass balance for $\mathrm{N}$ is given on the secondary $y$-axis as percentage from the beginning. B Correlation of $\mathrm{N}_{2}$-production with $\mathrm{NH}_{4}{ }^{+}$-consumption in flasks with constant $\mathrm{NO}_{2}^{-}$concentrations but with increasing amounts of $\mathrm{NH}_{4}{ }^{+}$. $\mathrm{N}_{2}$-production and $\mathrm{NH}_{4}{ }^{+}$-consumption were measured after 4 days. Error bars represent \pm one standard deviation from the mean of triplicate incubations. $\square$ Nitrite amount, ammonium amount, $\Delta$ amount of $\mathrm{N}_{2}, \diamond$ amount of nitrate, $\mathrm{O}$ total $\mathrm{N}$

observed (up to approximately $17 \mu \mathrm{m}$ in diameter, judged from electron micrographs). Cells within the clusters seemed embedded in an extracellular matrix, apparently holding the cells tightly together. The clusters in the electron micrographs consisted only of one type of bacterium, similar to the observations with fluorescence microscopy. Cells imaged in electron microscopy on freeze fractions and in thin sections displayed both an inner and an outer membrane, and a putative S-layer (Fig. 2). It was not possible to elucidate from freeze-fraction electron microscopy whether there were crateriform structures as described for Candidatus B. anammoxidans (Strous et al. 1999a). A high density, presumably protein-rich compartment was observed in the center of the cells (Fig.2). This structure might be similar to the ,anammoxosome" described for Candidatus B. anammoxidans (Strous 2000). Some cells displayed larger white areas that looked like membranes which had collapsed during fixation. Although there was a protein-rich area, the nitrogen content of dry mass of the anammox enrichment was only about $10 \%$. Approximately $46 \%$ of the dry weight was carbon, indicating no unusual carbon or nitrogen content (Egli 2000).

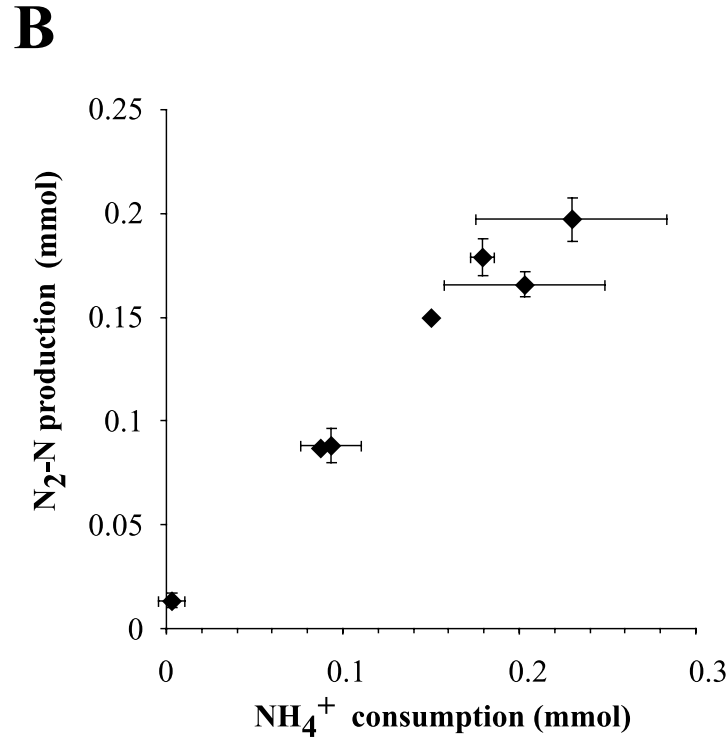

Physiology of anammox activity

To determine whether the enrichment culture from Kölliken was indeed performing the anammox reaction, several parameters in anoxic batch cultures were tested and changes in ammonium, nitrite, nitrate and $\mathrm{N}_{2}$-gas concentrations were measured. A decrease of ammonium and nitrite concentrations and a concomitant production of nitrate and $\mathrm{N}_{2}$ were observed only when both ammonium and nitrite were present (Fig. 3A). The rate of $\mathrm{N}_{2}$ production was approximately $24 \mathrm{nmol} \mathrm{N}_{2} \min ^{-1}$ (mg protein) $)^{-1}$. When only nitrite or ammonium was added to the enrichment culture, no $\mathrm{N}_{2}$ was produced and there was no change in nitrite or ammonium concentrations (Fig. 3A, inset). This indicates that classical nitrification and denitrification reactions did not play a significant role during anoxic incubations.

When the anammox culture was incubated with different ammonium concentrations $(0,2,4$ and $6 \mathrm{mM})$, but with the same nitrite concentration $(5 \mathrm{mM})$, the production of nitrate and $\mathrm{N}_{2}$ increased linearly with ammonium utilization (Fig. 3B). The overall stoichiometry of mol $\mathrm{N}_{2}-\mathrm{N}$ production per mol of ammonium utilized was not significantly different from 1 . In addition, nitrate production increased with nitrite utilization at an overall stoichiometry of $0.15 \mathrm{~mol}$ nitrate per mol nitrite, which is in agreement with the stoichiometries predicted for the anammox process by Candidatus B. anammoxidans (Strous et al. 1998).

To determine the optimal temperature for the Kölliken anammox organisms, we carried out incubations at 11, 20, $25,30,37$ and $45^{\circ} \mathrm{C}$. The highest anammox activity (as rate of $\mathrm{N}_{2}$ production) was observed at $37^{\circ} \mathrm{C}$. No anammox activity was observed at $45^{\circ} \mathrm{C}$ and the activity could not be restored by reducing the temperature to $37^{\circ} \mathrm{C}$. Anammox activity at $11^{\circ} \mathrm{C}$ was approximately $24 \%$ of that at $37^{\circ} \mathrm{C}$.

To investigate any inhibitory effects of nitrite, batch cultures with different nitrite concentrations were incu- 

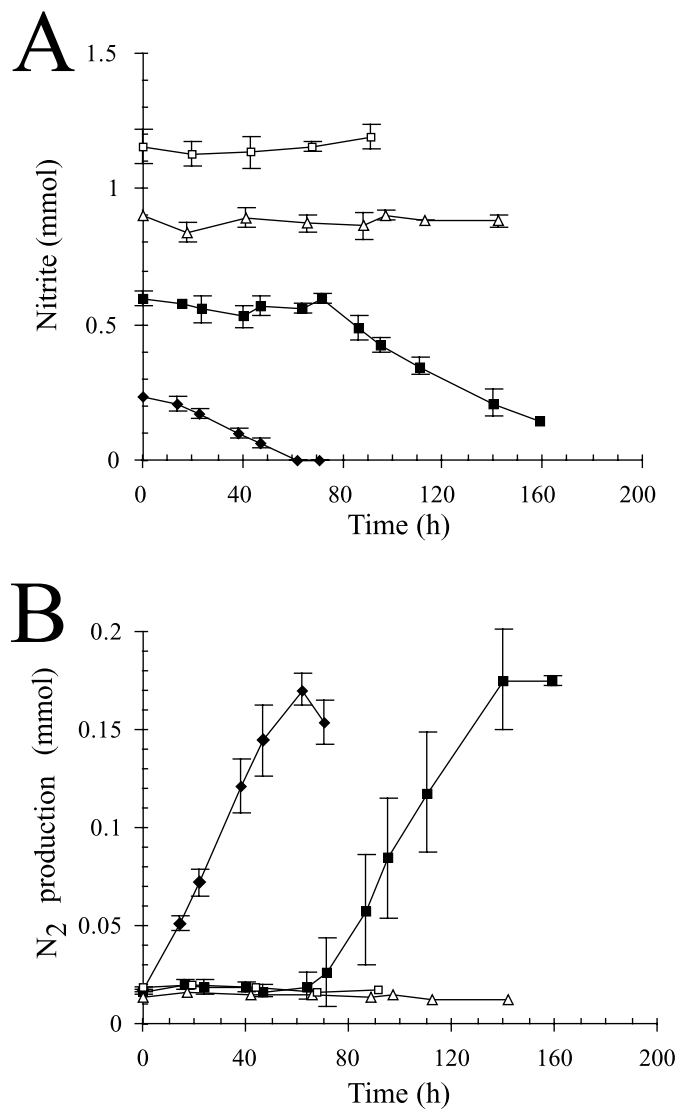

Fig. 4A, B Effect of increasing nitrite concentrations on the anammox activity of the enrichment culture incubated at the same ammonium concentration $(3 \mathrm{mM})$. A Nitrite concentrations and $\mathbf{B} \mathrm{N}_{2}$ production during incubation. $6 \mathrm{mM}$ Nitrite (corresponding to $0.25 \mathrm{mmol}$ per flask), $\square 12 \mathrm{mM}$ nitrite, $\Delta 18 \mathrm{mM}$ nitrite, $\square 24 \mathrm{mM}$ nitrite. Error bars represent \pm one standard deviation from the mean of triplicate incubations

bated, keeping the initial ammonium concentration constant. At $5.3 \mathrm{mM}$ nitrite, anammox activity started immediately (Fig.4), and, as expected, nitrogen and nitrate production stopped when all nitrite was consumed. At $13.2 \mathrm{mM}$ nitrite, anammox activity did not start until after 3 days (Fig. 4). Until then, no changes in the nitrite, ammonium and nitrate concentrations took place, and no $\mathrm{N}_{2}$ was produced. Anammox activity stopped when all ammonium was depleted. At higher initial nitrite concentrations, no anammox activity was observed within the tested period. The specific $\mathrm{N}_{2}$ production at 5.3 and $13.2 \mathrm{mM} \mathrm{ni-}$ trite and $\mathrm{pH} 7$ was similar at around $13 \mathrm{nmol} \mathrm{min}{ }^{-1}(\mathrm{mg}$ protein $)^{-1}$. The mean biomass concentration in all incubations was $65 \mu \mathrm{g}$ protein per $\mathrm{ml}$ culture and did not change significantly during the experiments. Therefore, practically no growth occurred during this 1-week experiment, which reflects the slow growth of anammox bacteria.

To test the effects of $\mathrm{pH}$ of the medium on anammox activity, batch cultures at $37^{\circ} \mathrm{C}$ were incubated with nitrite and ammonium at the following $\mathrm{pH}$ values: 6, 6.5, 7, $7.5,8,8.5$ and 9 . No anammox activity was observed at pH 6 and 6.5; ammonium and nitrite concentrations re-
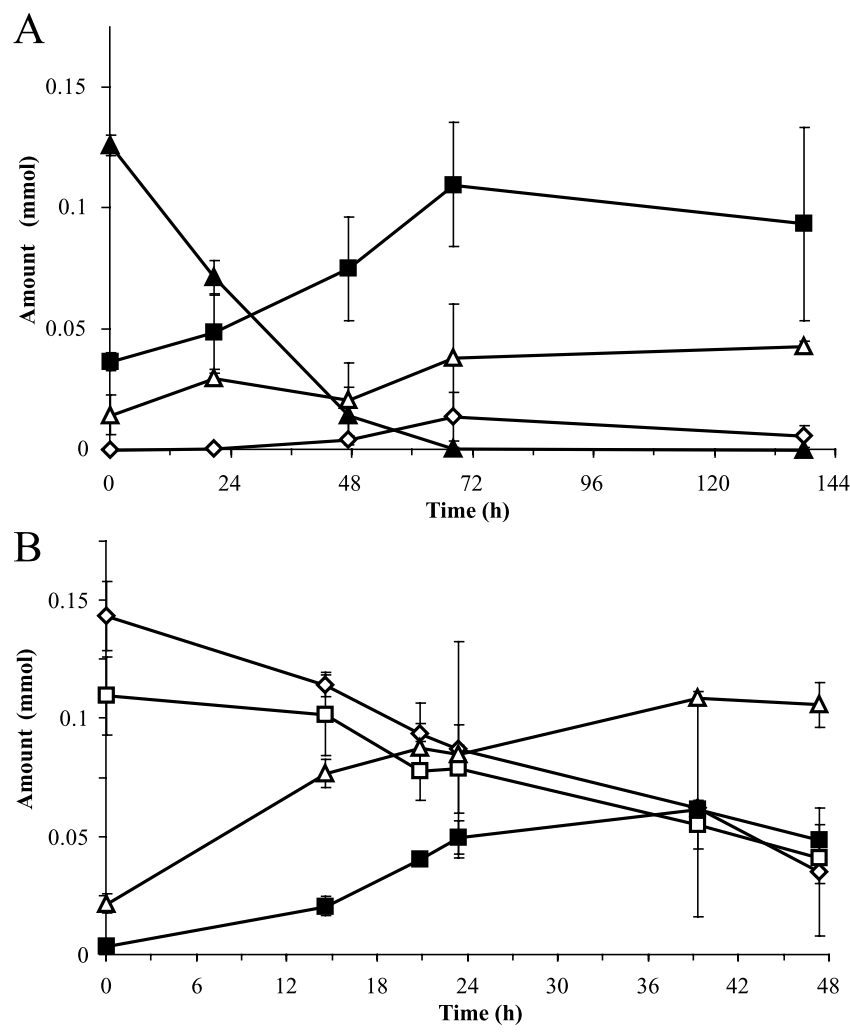

Fig.5A, B Addition of possible intermediates to the enrichment culture. A Conversion of hydroxylamine $\left(\boldsymbol{\Delta} \mathrm{NH}_{2} \mathrm{OH}\right)$ with ammonium (ם). B The parallel decrease of hydrazine $\left(\mathrm{N}_{2} \mathrm{H}_{4}\right.$, open diamonds) and nitrite $(\square)$. Error bars represent \pm one standard deviation from the mean of triplicate incubations. $\Delta$ represent amount of $\mathrm{N}_{2}$ produced

mained constant and neither $\mathrm{N}_{2}$ nor nitrate was produced (not shown). The highest activity was observed at $\mathrm{pH} 7.5$ and 8 [24 and $26.5 \mathrm{nmol} \mathrm{N}_{2} \mathrm{~min}^{-1}$ (mg protein) ${ }^{-1}$, respectively]. The $\mathrm{N}_{2}$-production rate at $\mathrm{pH} 7$ was $56 \%$ of the maximum. Anammox activity was also observed at $\mathrm{pH}$ 8.5 and 9. There was no significant difference in protein levels of cultures incubated at $\mathrm{pH} 7,7.5$ and 8 compared to those at $\mathrm{pH} 6$ and 6.5 (mean level: $20.9 \mu \mathrm{g}$ protein per $\mathrm{ml}$ culture), again indicating that practically no growth occurred during the batch incubations. The effect of $\mathrm{pH}$ was tested in buffer containing $20 \mathrm{mM}$ sodium phosphate. The $\mathrm{N}_{2}$-production rates with $20 \mathrm{mM}$ phosphate (at $\mathrm{pH} 7$ ) were essentially the same as with bicarbonate buffer (at $\mathrm{pH}$ 7), therefore, the anammox reaction was not inhibited by phosphate.

The sensitivity to oxygen was tested by adding different amounts of oxygen to the anoxic headspace in batch incubations. Initially, $0.25,0.5,1$ or $18 \%$ of oxygen saturation was present in the headspace. Within $16 \mathrm{~h}$, oxygen at the lowest concentrations $(0.25$ and $0.5 \%)$ had disappeared, probably due to any remaining aerobic microorganisms, and anammox activity started subsequently (data not shown). Anammox activity was also observed in bottles with $1 \%$ initial oxygen concentration, but again only after oxygen had disappeared. No anammox activity oc- 
curred within $64 \mathrm{~h}$ in bottles with $18 \%$ initial oxygen, and anammox activity could not be restored after oxygen was removed. This indicates a reversible inhibition of the anammox process at low oxygen concentrations, but irreversible inhibition at higher oxygen concentrations.

\section{Metabolic pathway for anammox conversion}

To confirm that the anammox organisms from the RBC in Kölliken were carrying out a reaction similar to that of Candidatus B. anammoxidans (Van de Graaf et al. 1997), we tested whether hydroxylamine and hydrazine were possible intermediates in anaerobic ammonium oxidation. In regular incubations with ammonium and nitrite (both at $5 \mathrm{mM}$ ), no hydroxylamine or hydrazine was detected at a concentration above the detection limit (i.e. $25 \mu \mathrm{M}$ and $10 \mu \mathrm{M})$. However, in incubations with $2.8 \mathrm{mM}$ hydroxylamine and $0.8 \mathrm{mM}$ ammonium, hydroxylamine was indeed disappearing (Fig.5A). Hydrazine was transiently produced (up to $0.31 \mathrm{mM}$ ), which is consistent with the hypothesis that ammonium is oxidized with hydroxylamine to hydrazine (Schalk et al. 1998). The concentrations of ammonium and $\mathrm{N}_{2}$ also increased during this experiment, possibly due to hydrazine disproportionation.

When hydrazine and nitrite were added to the enrichment culture, both compounds simultaneously disappeared at similar rates (Fig. 5B), which is consistent with the proposed reduction reaction of hydrazine and nitrite to form hydroxylamine. Ammonium and molecular nitrogen were also produced. The hydrazine concentration remained constant in sterile tubes (not shown), indicating that hydrazine disproportionation is a biologically mediated process.

\section{Discussion}

The results presented in this work show that microorganisms that carry out the anammox process could be enriched from biofilm material of the RBC in Kölliken. Although the experiments were not performed with a pure culture, we established that about $90 \%$ of the population was an anammox organism functionally similar to but taxonomically different than Candidatus B. anammoxidans. The 16S rDNA sequence obtained for the Kölliken anammox organism showed highest percentage of identity (between $98.5 \%$ and $98.9 \%$ ) to the $16 \mathrm{~S}$ rRNA gene sequences of Candidatus $K$. stuttgartiensis, a putative anammox organism in biofilm reactors in Stuttgart (Schmid et al. 2000). Other sequences from GenBank showed much lower percentages of identity (less than $86 \%$ ) to the sequence of the Kölliken organism. Based on several specific probe sequences developed for Candidatus $B$. anammoxidans and Candidatus $K$. stuttgartiensis, and based on other group-specific probes, we showed that $90 \%$ of the organisms in the Kölliken enrichment culture possessed the 16S rRNA gene identified in this work. Despite the significant difference in $16 \mathrm{~S}$ rDNA sequence of B. anam- moxidans and the Kölliken organism (9.1\%), their principal morphological properties were similar. Within the cells, a protein-rich region with lower content of ribosomes than the surrounding area was detected with electron microscopy and by FISH. In addition, the anammox organisms clumped in aggregates of up to 350 cells (judged from the electron micrographs and FISH pictures). The $16 \mathrm{~S}$ rDNA sequence information indicates that the anammox organisms from the Kölliken biofilm are most similar to Candidatus K. stuttgartiensis (Schmid et al. 2000) and therefore might be addressed with the same Candidatus Kuenenia genus name. Presently, it is not clear whether the few sequence differences found between the 16S rDNAs of Candidatus $K$. stuttgartiensis and the Kölliken organism represent true phylogenetic differences. However, since Candidatus $K$. stuttgartiensis was not further enriched to high relative population sizes (relative abundance in the biofilms $49 \%$ ), any physiological differences between the Kölliken and the Stuttgart anammox bacteria remain to be determined.

The physiological experiments confirmed that the Kölliken culture indeed performed the anammox process. $\mathrm{N}_{2}$ production took place when both ammonium and nitrite were present and oxygen was absent, but not when ammonium or nitrite was added alone. Still, the anoxic oxidation of ammonium with nitrite could also have been catalyzed by ,aerobic“ ammonium oxidizers of the genus $\mathrm{Ni}$ trosomonas (Bock et al. 1995), although the catalytic activity of these organisms is about 20-fold lower than that of Candidatus B. anammoxidans (Jetten et al. 1999). However, since no cells in the Kölliken enrichment stained positively in FISH with probes for $\beta$-Proteobacteria (which would detect Nitrosomonas), and for the genera Nitrospira and Nitrobacter, this strongly suggests that no classical ammonium- and nitrite-oxidizing bacteria were present at significant population sizes in the enrichment culture. Furthermore, when the nitrite concentration was kept constant, $\mathrm{N}_{2}$ production increased linearly with increasing ammonium consumption. Therefore, nitrite removal and $\mathrm{N}_{2}$ production could not be ascribed to denitrification, and ammonium removal could not be ascribed to nitrification at low oxygen levels. The concurrent removal of ammonium and nitrite with $\mathrm{N}_{2}$ production can only be reasonably explained by the anammox reaction, catalyzed by anammox bacteria.

Approximately $15 \%$ of the nitrite removed was oxidized to nitrate, which is similar to observations for Candidatus $B$. anammoxidans and seems to be due to the need for electrons to reduce $\mathrm{CO}_{2}$ for autotrophic growth (Van de Graaf et al. 1996). In addition, both hydroxylamine and hydrazine were converted by the enrichment culture, and a transient accumulation of hydrazine was observed when hydroxylamine was added, possibly due to condensation with ammonium. An increase in $\mathrm{N}_{2}$ and ammonium concentrations was also observed when hydroxylamine was added, possibly due to its disproportionation. These results suggest that the anammox reaction mediated by the Kölliken organism proceeds as proposed for Candidatus B. anammoxidans (Van de Graaf et al. 1996). 
Based on the relatively low percentage of identity of the 16S rDNA sequences of Candidatus B. anammoxidans and the Kölliken anammox organism, one might expect that the organisms would have physiological differences. However, our data showed only a few physiological differences. For example, the optimum $\mathrm{pH}$ and temperature of the two organisms were very similar. The Kölliken organism still showed activity at $\mathrm{pH} 9$, whereas Candidatus B. anammoxidans has an activity range between $\mathrm{pH} 6.7$ and 8.3 (Strous et al. 1999b). In addition, the Kölliken organisms exhibited higher tolerance to nitrite, up to $13 \mathrm{mM}$, compared to the $7 \mathrm{mM}$ reported for Candidatus $B$. anammoxidans (Strous et al. 1999b).

The highest observed anammox activity of the Kölliken organism (at $\mathrm{pH} 8$ and $37^{\circ} \mathrm{C}$ ) was $26.5 \mathrm{nmol} \mathrm{N}_{2}$ $\min ^{-1}$ (mg protein) $)^{-1}$, which is lower than that reported for Candidatus B. anammoxidans $\left[55 \mathrm{nmol}_{2} \mathrm{~min}^{-1}\right.$ (mg protein $)^{-1}$ at $\mathrm{pH} 8$ and $40^{\circ} \mathrm{C}$, Jetten et al. (1999)]. However, the Kölliken anammox organisms were active at low cell densities $\left(2 \times 10^{8}\right.$ cells per $\mathrm{ml}$ or $20 \mu \mathrm{g}$ protein per $\left.\mathrm{ml}\right)$, whereas the optimal activity of Candidatus $B$. anammoxidans was reached only in suspensions with a density higher than $10^{10}-10^{11}$ cells per $\mathrm{ml}$ (Strous et al. 1999a). Finally, there was no inhibitory effect of phosphate (up to $20 \mathrm{mM}$ tested) on the activity of the Kölliken culture compared to a loss of activity of Candidatus $B$. anammoxidans when incubated with more than $2 \mathrm{mM}$ phosphate (Van de Graaf et al. 1996). Perhaps this is due to a higher affinity of the Kölliken organism for hydrazine, which may be lost from the metabolic pathway by autooxidation. Autooxidation rates of hydrazine were reported to increase with increasing phosphate buffer concentrations (Moliner and Street 1989).

In conclusion, converging lines of evidence show mainly phylogenetic and slight physiological differences between Candidatus B. anammoxidans and the Kölliken anammox organism, although the main nitrogen transformation reactions appear to be identical.

Acknowledgments This work was funded by BUWAL (Swiss Agency for the Environment, Forests and Landscape), the Cantons of Luzern, St. Gallen and Zürich, the Buholz (Luzern) and Werhölzli (Zürich) wastewater treatment plants, and the Office for Waste Disposal, St. Gallen. We thank E. Wehrli for electron microscopy, M. Schmid and M. Wagner for confocal laser scanning microscopy, and C. Werlen for supporting the 16S rDNA sequencing.

\section{References}

Aiba H, Adhya S, de Crombrugghe (1981) Evidence for two functional gal promoters in intact Escherichia coli cells. J Biol Chem 256:11905-11910

Amann RI, Binder BI, Olson RJ, Chisholm SW, Devereux R, Stahl DA (1990) Combination of 16S rRNA-targeted oligonucleotide probes with flow cytometry for analyzing mixed microbial populations. Appl Environ Microbiol 56:1919-1925

Beijerinck MW, Minkman DCJ (1910) Bildung und Verbrauch von Stikoxydul durch Bacterien. Zentralbl Bakteriol Parasitenk, Abt. II 25:30-63
Bock E, Schmidt I, Stüven R, Zart D (1995) Nitrogen loss caused by denitrifying Nitrosomonas cells using ammonium or hydrogen as electron donors and nitrite as electron acceptor. Arch Microbiol 163:16-20

Broda E (1977) Two kinds of lithotrophs missing in nature. Z Allg Mikrobiol 17:491-493

Daims H, Nielsen PH, Nielsen JL, Juretschko S, Wagner M (2000) Novel Nitrospira-like bacteria as dominant nitrite-oxidizers in biofilms from wastewater treatment plants: diversity and in situ physiology. Water Sci Tech 41:85-90

Egli T (2000) Nutrition of microorganisms. In: Lederberg J (ed) Encyclopedia of microbiology, 2nd edn, vol 3. Academic, San Diego, pp 431-447

Frear DS, Burrell RC (1955) Spectrophotometric method for determining hydroxylamine reductase activity in higher plants. Anal Chem 27:1664-1665

Helmer C, Kunst S (1998) Simultanous nitrification/denitrification in an aerobic biofilm system. Water Sci Tech 57:183-187

Jetten MSM, Strous M, van de Pas-Schoonen KT, Schalk J, van Dongen UGJM, van de Graaf AA, Logemann S, Muyzer G, van Loosdrecht MCM, Kuenen JG (1999) The anaerobic oxidation of ammonium. FEMS Microbiol Rev 22:421-437

Kluyver AJ, Donker HJK (1926) Die Einheit in der Biochemie. Chem Zelle u Gewebe 13:134-190

Koch G, Egli K, van der Meer JR, Siegrist H (2000) Mathematical modeling of autotrophic denitrification in a nitrifying biofilm of a rotating biological contactor. Water Sci Tech 41:191-198

Manz W, Amann R, Ludwig W, Wagner M, Schleifer K-H (1992) Phylogenetic oligonucleotide probes for the major subclasses of Proteobacteria: problems and solutions. Syst Appl Microbiol 15:593-600

Moliner AM, Street JJ (1989) Decomposition of hydrazine in aqueous solutions. J Environ Qual 18:483-487

Mulder A, van de Graaf AA, Robertson LA, Kuenen JG (1995) Anaerobic ammonium oxidation discovered in a denitrifying fluidized bed reactor. FEMS Microbiol Ecol 16:177-184

Neef A, Amann R, Schlesner H, Schleifer K-H (1998) Monitoring a widespread bacterial group: in situ detection of planctomycetes with $16 \mathrm{~S}$ rRNA-targeted probes. Microbiology 144: 3257-3266

Pearson DJ, Lipman WR (1988) Improved tools for biological sequence analysis. Proc Natl Acad Sci USA 85:2444-2448

Sambrook J, Fritsch EF, Maniatis T (1989) Molecular cloning: a laboratory manual, 2nd edn. Cold Spring Harbor Laboratory, Cold Spring Harbor, New York

Schalk J, Oustad H, Kuenen JG, Jetten MS (1998) The anaerobic oxidation of hydrazine: a novel reaction in microbial nitrogen metabolism. FEMS Microbiol Lett 158:61-67

Scheiner D (1976) Determination of ammonia and kjeldahl nitrogen by indophenol method. Water Res 10:31-36

Schmid M, Twachtmann U, Klein M, Strous M, Juretschko S, Jetten M, Metzger JW, Schleifer K-H, Wagner M (2000) Molecular evidence for genus-level diversity of bacteria capable of catalyzing anaerobic ammonium oxidation. Syst Appl Microbiol 23:93-106

Siegrist H, Reithaar S, Koch G, Lais P (1998) Nitrogen loss in a nitrifying rotating contactor treating ammonium-rich wastewater without organic carbon. Water Sci Tech 38:241-248

Strous M (2000) Microbiology of anaerobic ammonium oxidation. PhD thesis, Technical University Delft (The Netherlands)

Strous M, van Gerven E, Kuenen JG, Jetten MSM (1997) Effects of aerobic and microaerobic conditions on anaerobic ammonium oxidizing (anammox) sludge. Appl Environ Microbiol 63:2446-2448

Strous M, Heijnen JJ, Kuenen JG, Jetten MSM (1998) The sequencing batch reactor as a powerful tool for the study of slowly growing anaerobic ammonium-oxidizing microorganisms. Appl Microbiol Biotechnol 50:589-596

Strous M, Fuerst JA, Kramer EHM, Logemann S, Muyzer G, van de Pas-Schoonen KT, Webb R., Kuenen JG, Jetten MSM (1999a) Missing litotroph identified as new planctomycete. Nature 400:446-449 
Strous M, Kuenen JG, Jetten MSM (1999b) Key physiology of anaerobic ammonium oxidation. Appl Environ Microbiol 65: $3248-3250$

Van de Graaf AA, Mulder A, de Bruijn P, Jetten MSM, Roberston LA, Kuenen JG (1995) Anaerobic oxidation of ammonium is a biologically mediated process. Appl Environ Microbiol 61: 1246-1251

Van de Graaf AA, de Bruijn P, Roberston LA, Jetten MSM, Kuenen JG (1996) Autotrophic growth anaerobic ammonium-oxidizing micro-organims in a fluidized bed reactor. Microbiology 142:2187-2196

Van de Graaf AA, de Bruijn P, Roberston LA, Jetten MSM, Kuenen JG (1997) Metabolic pathway of anaerobic ammonium oxidation on the basis of ${ }^{15} \mathrm{~N}$ studies in a fluidized bed reactor. Microbiology 143:2415-2421
Wagner M, Rath G, Koops H-P, Flood J, Amann R (1996) In situ analysis of nitrifying bacteria in sewage treatment plants. Water Sci Tech 34:237-244

Watt G (1952) A spectrophotometric method for the determination of hydrazine. Anal Chem 24:2006-2008

Wehrli E, Egli T (1988) Morphology of nitriloacetate-utilizing bacteria. Syst Appl Microbiol 10:306-312

Winogradsky S (1890) Recherches sur les organismes de la nitrification. Ann Inst Pasteur 4:213-231 